\title{
The Variability of the Tunisian Real Exchange Rate
}

\author{
Zouhaier Hadhek ${ }^{1}$, Hniya Sakli ${ }^{2}$ \& Tahar Lassoued ${ }^{1}$ \\ ${ }^{1}$ Higher Institute of Management of Gabès, University of Gabès, Tunisia \\ ${ }^{2} \mathrm{PhD}$ Student in Economics, University of Sfax, Tunisia \\ Correspondence: Zouhaier Hadhek, Higher Institute of Management of Gabès, University of Gabès, Tunisia, rue \\ Jilani Habib 6002, Gabès, Tunisia. Tel: 216-97-388-013. E-mail: hzouhair2000@yahoo.fr
}

Received: November 13, 2018

Accepted: December 20, 2018

Online Published: December 25, 2018

doi:10.5539/ijef.v11n1p115

URL: https://doi.org/10.5539/ijef.v11n1p115

\begin{abstract}
This article presents an estimate of the equilibrium real exchange rate for Tunisia using the model of Edwards (1998) and Elbadawi (1994). We calculate the distortion between the actual RER and the equilibrium RER and the misalignments related thereto. The study period was marked by phases of overvaluation and undervaluation of the RER.
\end{abstract}

Keywords: equilibrium real exchange rate, misalignment, cointegration

\section{Introduction}

The evolution of a country's competitiveness vis-à-vis the rest of the world can be assessed by comparing the real effective exchange rate (REER) to its equilibrium level, or by determining the RER misalignment. Thus, the latter is defined as the difference between the actual real exchange rate and the equilibrium real exchange rate. The RER is overvalued when it is appreciated relative to its equilibrium rate, while, it is undervalued when it is depreciated compared to RER of Balance. Misalignment, whether positive or negative, reflects a bad exchange rate policy, which may lead to the crisis (the Asian crisis of the 90s).

Theoretically, the overvaluation of the national currency has a negative effect on growth and economic performance. Indeed, it leads to a misallocation of resources (Edwards, 1988, 1989; Dornbusch, 1988; Cottani \& alii, 1990; Ghura \& Grennes, 1993; Domaç \& Shabsigh, 1999; Gylfason, 2002; Aguirre \& Calderón, 2005; Easterly, 2005; Johnson \& alii, 2007; Jongwanich, 2009; Diallo, 2011). The persistence of overvaluation can be seen as a precursor to the crisis (Edwards, 1989 and 2000; Williamson, 1983 and 1994; Stein \& Allen, 1995), and which also constitutes a currency crash indicator (Krugman, 1979b; Frankel \& Rose, 1996; Kaminsky \& Reinhart, 1999).

On the contrary, undervaluation appears to be more beneficial. It helps to boost the performance of the export sector and overall economic activity (Aguirre \& Calderón, 2005). Thus, it leads to an increase in the share of tradable goods in the national value added. However, it may be conducive to growth (Musyoki et al., 2012; Lévy-Yeyati \& Sturzenegger, 2007; and Rodrik, 2009), and lead to an increase in the share of tradable goods in national value added. According to LévyYeyati and Sturzenegger, undervaluation increases production and productivity. However, when it persists, it can cause economic overheating, which puts pressure on domestic prices and leads to a misallocation of resources between tradable and non-tradable goods sectors (Jongwanich, 2009).

\section{RER' Determinants}

\subsection{Terms of Trade and RER}

In theory, the change in the terms of trade is regarded as an important source of fluctuations of RER. However, the final effect on the RER may not be known a priori because of the existence of two effects (Aliyu, 2007): an income effect and a substitution effect

- The income effect: following a reduction of import tariffs, the domestic price of import decreases. Thus, a positive income effect generates an increase in demand for non-tradable and importable goods .To absorb the excess demand for non-tradable goods, the non-tradable price must be increased and therefore, it generates an appreciation of the equilibrium RER; 
- The substitution effect: lower import tariffs make imports cheaper than non-tradable goods. Then, the excess supply of non-tradable goods will be corrected by a reduction in non-tradable prices, and thus by a depreciation of the equilibrium RER.

Briefly, the net effect of the terms of trade on the equilibrium RER depends on the dominating effect: if the income effect outweighs the substitution effect, then the improvement in the terms of the exchange will generate an appreciation in the RER (Domaç \& Shabsigh, 1999; Bogoev et al., 200; AlShehabi \& Ding, 2008). Conversely, deterioration in the terms of trade tends to appreciate the equilibrium RER if the substitution effect is not only positive but also above the income effect. Otherwise, depreciation in the RER will take place.

\subsection{Trade Opening And RER}

The trade openness policy is a potential source that affects the RER. Thus, a tariff reduction can decrease the domestic prices of imports. This will generate a decline in prices of tradable goods, and therefore creates an appreciation of the RER. However, greater trade liberalization leads to a depreciation of the RER, since it allows for increased trade and price convergence (Goldfajn \& Valdes, 1999; IEQ, 2003; Drine \& Rault, 2005). This depreciation allows to absorb excess labor from the importable goods sector (Goldfajn \& Valdés, 1999). Studies of the IEQ (2003), Hadj Amor and El Araj (2009) on the MENA countries and Drine and Rault (2005) on Africa, Asia and Latin America confirm the negative relationship between trade openness, Technological progress and RER.

\subsection{Technological Progress and the RER}

Technological progress can take two different forms: technological progress that increases the product 'income augmenting' and technological progress that increases the factors of production 'factor augmenting' (Balassa, 1964).

- Technological progress 'income augmenting' increases real incomes, and thus it creates excess demand for consumables. Since technological progress is less important in the non-tradable goods sector than in the tradable goods sector, then the price of non-tradable goods will tend to increase more slowly than the price of tradable goods, an appreciation of the RER will take place.

- Technological progress 'factor augmenting' allows having a bigger production with the same quantity of production factors. Thus, the excess supply will be corrected by a fall in the prices of non-tradable goods and thus by a depreciation of the equilibrium RER (De Gregorion \& Wolf, 1994).

\subsection{Capital Flows and RER}

The long-term impact of foreign capital flows on the RER is associated with a real appreciation (Edwards, 1989, 1994; Athukorala \& Rajapatirana, 2003). According to Toma (2006), the effect of long-term capital movements depends on the use of these assets. If this capital has been used to promote the competitiveness of the economy and improve productivity in the tradable goods sector, then the final effect will be an appreciation of the RER. However, if the use of the capital flows generates an increase in consumption, then the initial appreciation of the RER will be followed by a real long-term depreciation.

Edwards (1994) points out that liberalization of the capital account produces an appreciation of the equilibrium RER. Indeed, a reduction in taxes on external borrowing makes future consumption more expensive and encourages agents to substitute their future consumption for current consumption. Thus, there is pressure on the price of non-tradable goods while producing a real appreciation of the equilibrium RER. However, lowering taxes on external borrowing reduces distortions in the economy by creating a positive welfare effect through a positive income effect. The latter increases consumption and generates a real appreciation of the equilibrium RER.

\section{Estimating the Misalignment of the Real Exchange Rate}

The analysis of the behavior of the RER will be conducted following the co-integration technique applied to non-stationary series. Before proceeding to the estimation of the model, we will first describe the variables used in our regression.

\subsection{Choice of Variables}

We study the relationship between RER and some macroeconomic fundamentals that are considered relevant in our work, and which are also expected to influence internal and external macroeconomic balance. The fundamentals retained in our model were chosen based on theoretical analysis and data availability. The most statistically significant fundamental variables are productivity, terms of trade, trade openness and capital flows. 
Terms of trade (TOT):

They are calculated as the ratio of export prices (unit value index) to import prices (unit value index) of Tunisia. They may lead to real appreciation or depreciation depending on the significance of income effects and substitution effects.

Commercial opening (OP):

It is expressed as the sum of imports and exports relative to GDP. Given that the Tunisian economy is following a policy of trade liberalization, the relationship between openness and RER is expected to be negative.

GDP per capita (GDP)

It is represented by GDP per capita. It captures the Balassa-Samuelson effect that fast-growing countries tend to experience a real appreciation of their exchange rate.

Capital flows (FDI):

Capital flows are usually materialized in the form of FDI or portfolio investment (PFI). However, the IPF are not crucial sources of financing for the Tunisian economy, therefore they will not be included in our model. As a result, capital flows will be composed solely of FDI. Thus, an increase in FDI leads to a real appreciation of the exchange rate.

\section{Current account balance (CAB)}

A current account deficit leads to an increase in net external debt that can be financed by various international investments (MacDonald \& Ricci, 2003; Chudik \& Mongardini, 2007). Since the Tunisian current account is still in deficit, expected relationship between the current account balance and the RER can only be negative.

The symbols and definitions of the different variables used in our model are described in Table 1 below. All these variables are expressed in natural logarithms (denoted $\mathrm{lx}$ for the variable $\mathrm{x}$, except the variable 'current account balance'):

Table 1. Variables used in our model

\begin{tabular}{cl}
\hline Symbol of the variable used in the model & Meaning of the variable used in the model \\
\hline LREER & The logarithm of the real effective exchange rate (quoted at the uncertain) \\
LTOT & The logarithm of the terms of trade \\
LFDI & The logarithm of foreign direct investment flows as a percentage of GDP \\
LGDP & The logarithm of GDP per capita \\
LOP & The logarithm of the degree of trade openness \\
CAB & The current account balance \\
\hline
\end{tabular}

The data is extracted from the following sources:

- The Real Effective Exchange Rate is available in the IMF's International Financial Statistics (IFS) database,

- The terms of trade and the current account balance are available on the website of the World Bank,

- The commercial opening is calculated from the IFS data,

- The GDP per capita and the FDI are provided by the World Bank,

The data in our study are annual and cover the period 1980-2015

\subsection{Stationarity and Cointegration Tests}

\subsubsection{The Unit Root Test}

The purpose of the unit root test is to determine the order of integration of the variables. Table 2 below summarizes the results of the enhanced Dickey-Fuller (ADF) test.

Table 2. Results of ADF test

\begin{tabular}{lccccc}
\hline Variables & Stationarity & t-stat & Critical Value & Prob & Results \\
\hline LREER & in level & $-1,3400$ & $-3,5402$ & 0,8613 & non-stationary \\
& In first differences & $-2,9664$ & $-2,6128$ & 0,0481 & stationary \\
LTOT & in level & $-1,8742$ & $-3,5442$ & 0,6464 & non-stationary \\
& In first differences & $-4,2866$ & $-3,5442$ & 0,0090 & stationary \\
\hline
\end{tabular}




\begin{tabular}{lccccc}
\hline LFDI & in level & $-3,4200$ & $-4,2349$ & 0,0645 & non-stationary \\
& In first differences & $-8,1902$ & $-3,5442$ & 0,0000 & stationary \\
LOP & in level & $-2,7265$ & $-3,5403$ & 0,2326 & non-stationary \\
& In first differences & $-5,5883$ & $-3,5442$ & 0,0003 & stationary \\
LGDP & in level & $-0,3750$ & $-2,9458$ & 0,9030 & non-stationary \\
& In first differences & $-4,7756$ & $-2,9484$ & 0,0005 & Stationary \\
CAB & in level & $-2,1110$ & $-3,5403$ & 0,5225 & non-stationary \\
& In first differences & $-5,8889$ & $-3,5442$ & 0,0001 & Stationary \\
\hline
\end{tabular}

The results of the ADF test showed that the variables are non-stationary in level since the ADF statistic is greater than the critical value. While, in first difference, all the variables are stationary because the ADF statistic is lower than the critical value. We deduce that all variables are integrated in the same order I(1).

\subsubsection{Cointegration Test}

The cointegration test allows us to check if there is a long-term relationship between non stationary variables. Two cases arise: in the absence of a wedge-integration relation, we estimate an autoregressive model, whereas, if there is a cointegeration relation, we must estimate an error-correction model (ECM).

Table 3. Results of trace statistics

\begin{tabular}{ccccc}
\hline Null Hypothesis & Eigenvalue & Trace Statistic & Critical Value & P-value \\
\hline None & 0.893798 & 222.9774 & 117.7082 & 0.0000 \\
At most 1 & 0.835747 & 146.7353 & 88.80380 & 0.0000 \\
At most 2 & 0.611716 & 85.31940 & 63.87610 & 0.0003 \\
At most 3 & 0.511887 & 53.15477 & 42.91525 & 0.0035 \\
At most 4 & 0.427099 & 28.76969 & 25.87211 & 0.0212 \\
At most 5 & 0.251082 & 9.830259 & 12.51798 & 0.1351 \\
\hline
\end{tabular}

Table 4. Results of maximal eigen statistics

\begin{tabular}{ccccc}
\hline Null Hypothesis & Eigenvalue & Maximal Eigen statistics & Critical Value & P-value \\
\hline None & 0.893798 & 76.24215 & 44.49720 & 0.0000 \\
At most 1 & 0.835747 & 61.41588 & 38.33101 & 0.0000 \\
At most 2 & 0.611716 & 32.16463 & 32.11832 & 0.0493 \\
At most 3 & 0.511887 & 24.38508 & 25.82321 & 0.0765 \\
At most 4 & 0.427099 & 18.93943 & 19.38704 & 0.0580 \\
At most 5 & 0.251082 & 9.830259 & 12.51798 & 0.1351 \\
\hline
\end{tabular}

Johansen's trace and maximum eigenvalue statistics showed the existence of at least one cointegrating relationship. Thus, the trace test indicates the existence of five cointegrating vectors at $5 \%$. While, the maximum eigenvalue statistics indicates the existence of three cointegrating vectors at $5 \%$.

\subsection{Estimation Results}

Table 5 below presents the long-term relationship between RER and macroeconomic fundamentals.

Table 5. Estimation of the long-run relationship between the equilibrium RER and macroeconomic fundamentals

\begin{tabular}{llllll}
\hline & \multicolumn{5}{c}{ Determinants of the equilibrium RER } \\
\hline & LOP & LTOT & LFDI & LGDP & LCAB \\
\hline Coeff & $-0,62$ & 0,65 & 0,03 & 0,34 & $-0,01$ \\
T.Stat & 10,01 & 13,08 & 3,77 & 6,93 & 5,88 \\
\hline
\end{tabular}

The negative coefficient corresponding to the trade opening variable supports the idea that trade liberalization is accompanied by a depreciation of the RER. Thus, a 10\% improvement in the degree of openness of the Tunisian economy generates a real depreciation of around $6.2 \%$.

For the variable 'terms of trade, the empirical results show that an improvement in the terms of trade leads to an appreciation of the RER, thus implementing an income effect that dominates the income effect. Then an 
improvement in the terms of trade of $10 \%$ leads to an appreciation of $6.5 \%$ of the real value of Tunisian dinar.

The long relationship between FDI and RER fits well into the theoretical predictions. Indeed, the cointegration coefficient for FDI is positive; indicating that an increase in foreign capital inflows leads to an increase in domestic demand whose reallocation of factors of production is in favor of non-tradable sectors. This rise in demand for non-tradable goods allows the real exchange rate to be raised in the long run. Thus, an increase in foreign capital flows of $10 \%$ generates an appreciation of $0.3 \%$ of the real value of Tunisian Dinar.

Regarding the relationship between the current account balance and RER, it fits well in the theoretical predictions. Thus, the current account deficit generates a real depreciation of the RER equilibrium.

The effect of per capita income on the RER contributes to long-run changes in the RER. The positive coefficient corresponding to the productivity variable implies that the economic development is accompanied by an appreciation of the RER (Balassa-Samuelson effect).

Regarding the short-term of the equilibrium RER, it was examined by estimating an error correction model (ECM).

Table 6. Estimation of ECM

\begin{tabular}{lllllll}
\hline \multicolumn{7}{c}{ The short-term of the equilibrium RER } \\
\hline Coeff & $\Delta$ TOT & $\Delta$ FDI & $\Delta G D P$ & $\Delta O P$ & $\Delta C A B$ & ECM \\
T.Stat & 0,04 & 0,58 & $-0,14$ & $-0,22$ & 0,09 & $-0,11$ \\
\hline
\end{tabular}

We note that the TOT, FDI and trade openness, exert on the RER the same effects already found in the long-term relationship. While, the GDP per capita and the current account balance occur in contrast to their effect under steady-state conditions.

The coefficient associated with the error correction term is negative and statistically significant. This indicates a gradual convergence of the equilibrium RER towards its long-term value.

To determine the equilibrium RER, it is necessary to replace the fundamentals by their sustainable values. Most authors choose to replace fundamentals with their multi-year moving averages (Edwards, 1989; El Badawi, 1994).

The following Figure shows the evolution of the actual RER compared to its equilibrium value.

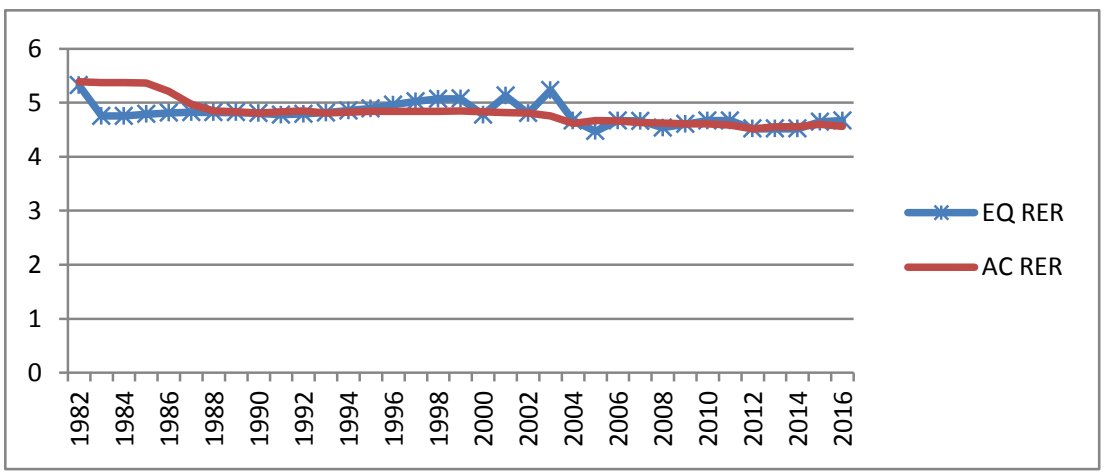

Figure 1. Evolution of the actual RER and the equilibrium RER

Source: Author's estimations.

Once the equilibrium RER has been determined, it is possible to calculate the RER misalignment, which is defined as the difference between the actual RER (FMI base) and the equilibrium RER.

Analytically, the measurement of the misalignments is done according to the following formula:

$$
M I S_{t}=\frac{A C R E R_{t}-E Q R E R_{t}}{E Q R E R_{t}}
$$

$E Q R E R_{t}$ is the equilibrium RER; $A C R E R_{t}$ is the actual RER. 


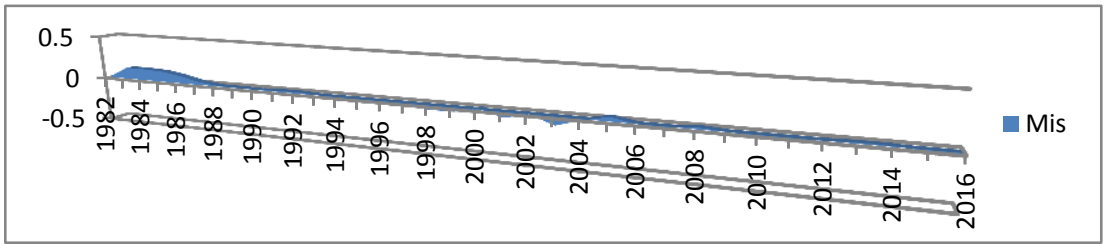

Figure 2. Misalignment of the Tunisian Dinar

Source: Author's estimations.

It can be seen in Figure A4 below that, before the adoption of the SAP, the divergence of the RER from its equilibrium value is very important. This discrepancy between the actual RER and its equilibrium value can only aggravate the country's economic crisis, which ended with a devaluation of the Tunisian Dinar under the SAP. Starting in 1988, the actual RER revolves around a constant value. Thus, the 1986 devaluation was justified by the model as that from 1988 to 1994 when the actual value of the RER merges with its equilibrium value. The end of the 90s was marked by an important underestimation, therefore, we can say that Tunisia could not preserve its competitiveness. During the period 2000-2015, except for the year 2006, Tunisia has sharply reduced the fluctuations in the value of its currency.

\section{Conclusions}

The aim of this paper is to estimate the equilibrium RER for Tunisia .The estimate covers 35 observations over the period from 1980 to 2015. First, we have determined the equilibrium RER by means of the cointegration relationship, and second, the equilibrium values of the fundamentals which are moving averages over three years. Then, the equilibrium RER is explained by economic fundamentals. Afterwards, we calculated the misalignment, which is the difference between the actual RER and the long-term RER.

The study period was marked by phases of overvaluation and undervaluation of the RER. Our study shows that an improvement in the TOT , an increase in the degree of openness, and a rise in income per capita lead to a long-term appreciation in the real exchange rate. In contrast, an increase in the degree of openness of the Tunisian economy and a deficit in the current account lead to depreciation in the real exchange rate.

\section{References}

Aguirre, A., \& Calderón, C. (2005). Real Exchange Rate Misalignments and Economic Performance. Central Bank Of Chile, Working Papers, $N^{\circ} 315$, Abril.

Aliyu, S. U. R. (2007). Real Exchange Rate Misalignment: An Application of Behavioral Equilibrium Exchange Rate (BEER) to Nigeria. MPRA Paper $N^{\circ} 10376$, Bayero University Kano, Nigeria, September.

AlShehabi, O., \& Ding, S. (2008). Estimating Equilibrium Exchange Rates for Armenia and Georgia. IMF Working Paper $N^{\circ} 08 / 110$, April.

Athukorala, P. C., \& Rajapatirana, S. (2003). Capital Inflows and the Real Exchange Rate: A Comparative Study of Asia and Latin America. The World Economy, 26(4), 613-637. https://doi.org/10.1111/1467-9701.00539

Balassa, B. (1964). The Purchasing-Power Parity Doctrine: A Reappraisal. Journal of Political Economy, 72, 584-596. https://doi.org/10.1086/258965

Benahji, H. S. (2008). Choix Des Politiques De Change Dans Les Pays En Developpements: Etude De La Competitivite De La Tunisie. Panoeconomicus, 3, 353-367. https://doi.org/10.2298/PAN0803353B

Charfi, F. M. (2008). TCR D'équilibre Et Mésalignements: Enseignements D'un Modèle VAR-ECM Pour Le Cas De La Tunisie. Panoeconomicus, 4, 439-464. https://doi.org/10.2298/PAN0804439C

Cottani, J. A., Cavallo, D. F., \& Khan, M. S. (1990). Real Exchange Rate Behavior and Economic Performance In Ldcs. Economic Development and Cultural Change, 39, 61-76. https://doi.org/10.1086/451853

De Gregorio, J., \& Wolf, H. (1994). Terms of Trade, Productivity, and the Real Exchange Rate. NBER Working Papers 4807. https://doi.org/10.3386/w4807

Diallo, I. A. (2011). The Effects of Real Exchange Rate Misalignment and Real Exchange Volatility on Exports. Clermont University, University Of Auvergne, Centre d'Etudes Et De Recherches Sur Le Développement International, CERDI, April.

Domaç, I., \& Shabsigh, G. (1999). Real Exchange Rate Behaviour and Economic Rate Growth: Evidence from Egypt, Jordan, Morocco and Tunisia. IMF Working Paper (pp.10-11), WP/99/40, Washington D.C. 
Dornbusch, R. (1988). Overvaluation and Trade Balance. In R. Dornbusch, \& F. Helmers (Eds.), The Open Economy: Tools For Policymakers In Developing Countries (pp. 80-107). Washington D.C.: Oxford University Press.

Drine, I., \& Rault, C. (2005). Déterminants De Long Terme Des TCR Pour Les Pays En Développement: Une Comparaison Internationale. Revue D'économie $D u$ Développement, 19, 123-150. https://doi.org/10.3917/edd.191.123

Edwards, S. (1988). Exchange Rate Misalignment in Developing Countries. Published for the World Bank, Occusional Paper $N^{\circ} 2 / N e w$ Series. Baltimore MD: The Johns Hopkins Unibersity Press.

Edwards, S. (1994). Real and Monetary Determinants of Real Exchange Rate Behavior: Theory and Evidence from Developing Countries. In J. Williamson (Ed.), Estimating Equilibrium Exchanges Rates. Institute For International Economics, Washington.

Frankel, J. A., \& Rose, A. K. (1996). Currency Crashes In Emerging Markets: An Empirical Treatment. Journal of International Economics, 41(3-4), 351-366. https://doi.org/10.1016/S0022-1996(96)01441-9

Ghura, D., \& Grennes, T. (1993). The Real Exchange Rate And Macroeconomic Performance in Sub-Saharan Africa. Journal of Development Economics, 42, 155-174. https://doi.org/10.1016/0304-3878(93)90077-Z

Goldfajn, I., \& Valdés, R. (1999). The Aftermath of Appreciations. Quarterly Journal of Economics, 114, 229-62. https://doi.org/10.1162/003355399555990

Gylfason, T. (2002). The Real Exchange Rate Always Floats. Center For Economic Policy Research (CEPR), Discussion Paper Series, No. 3376, London. https://doi.org/10.1111/1467-8454.00171

Hadj, A. T., \& El Araj, R. (2009). Dynamique A Long Terme Du TCR, Libéralisation Commerciale Et Intégration Financière: Cas Des Pays Du Sud Et De l'Est Méditerranéen. Panoeconomicus, 1, 73-93.

Jongwanich, J. (2009). Equilibrium Real Exchange Rate, Misalignment, and Export Performance in Developing Asia. ADB Economics Working Paper Series $N^{\circ} 151$. https://doi.org/10.2139/ssrn.1604839

Kaminsky, G., \& Reinhart, C. M. (1999). The Twin Crises: The Causes of Banking and Balance of Payments Problems. American Economic Review, 89(3), 473-500. https://doi.org/10.1257/aer.89.3.473

Krugman, P. (1979b). A Model Of Balance-Of-Payments Crises. Journal of Money, Credit, and Banking, 11(3), 311-325. https://doi.org/10.2307/1991793

Musyoki, D., Pokhariyal, G. P., \& Pundo, M. (2012). Real Exchange Rate Equilibrium and Misalignment in Kenya. Journal of Business Studies Quarterly, 3(4).

Rodrik, D. (2008). The Real Exchange Rate and Economic Growth. Brookings Papers on Economic Activity, 2, 365-412.

Stein, J. L., \& Allen, P. R. (1995). Fundamental Determinants Of Exchange Rates. Oxford: Clarendon Press.

Toma, R. (2006). Real Exchange Rate And Competitiveness in Romania. Studies in Business and Economics, $1(1), 60-65$.

Williamson, J. (1983). The Exchange Rate System, Policy Analyses in International Economics, $N^{\circ} 5$. Washington: Institute For International Economics, September (Also Revised Edition, June 1985).

Williamson, J. (1994). Estimates of Feers. In J. Williamson (Ed.), Estimating Equilibrium Exchanges Rates. Institute For International Economics, Washington.

\section{Appendix A. The determinants of the RER}

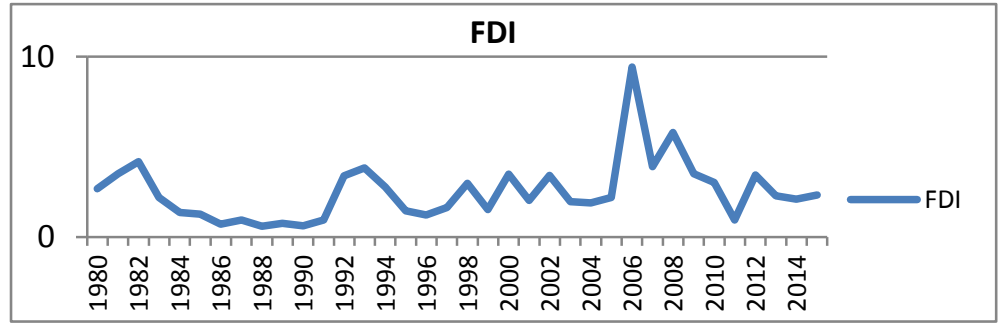

Figure A1. Evolution of FDI

Source: WB. 


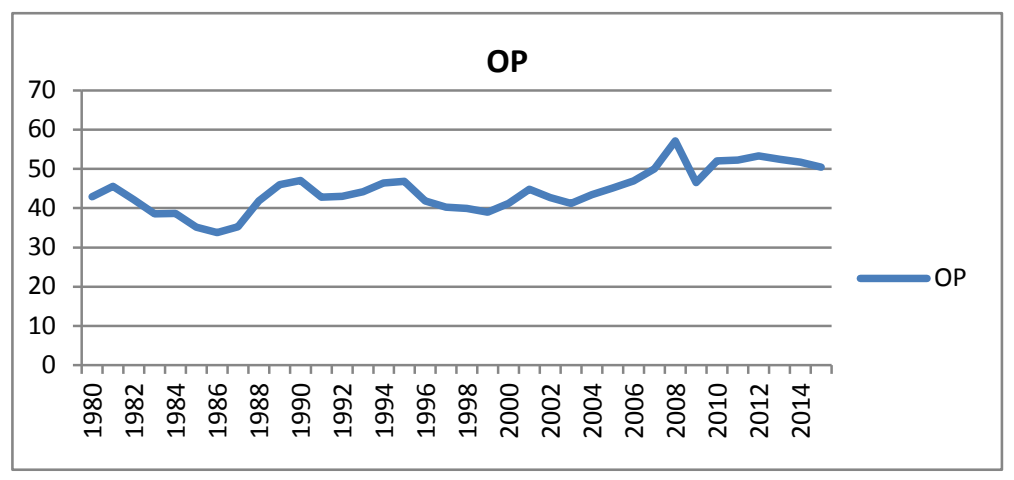

Figure A2. Evolution of OP

Source: WB.

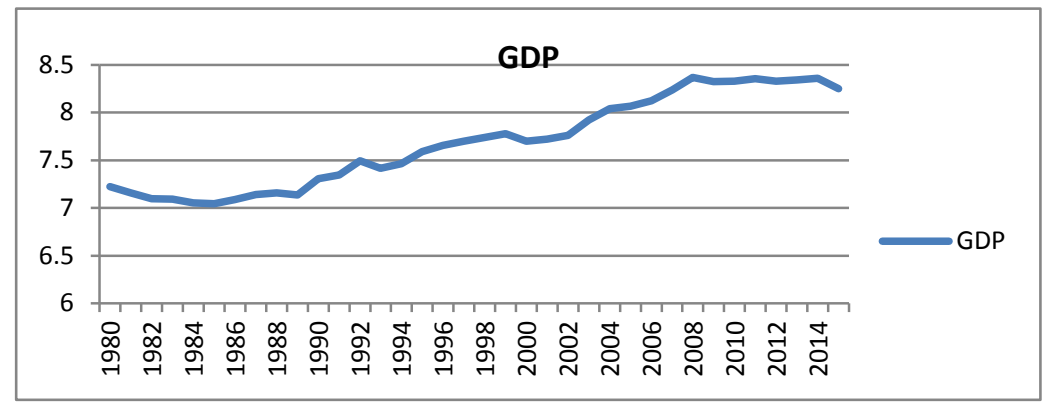

Figure A3. Evolution of GDP

Source: WB.

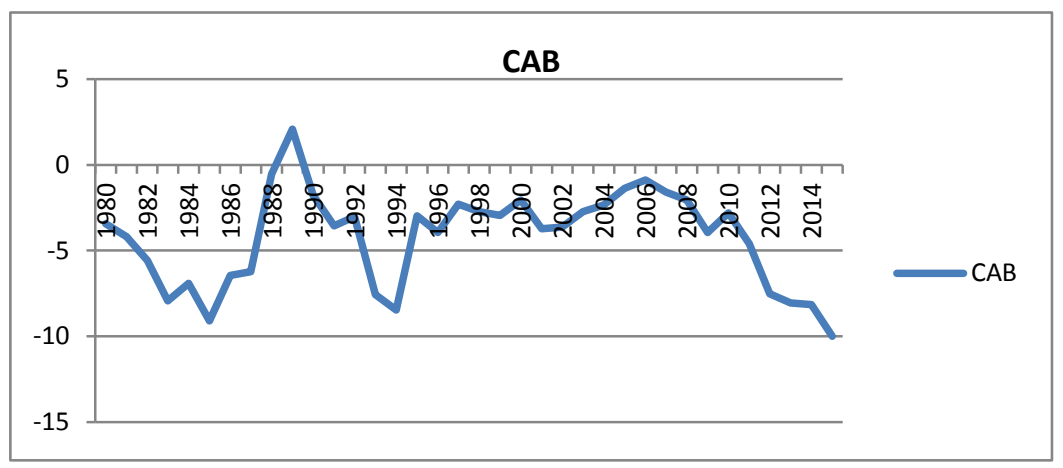

Figure A4. Evolution of CAB

Source: WB.

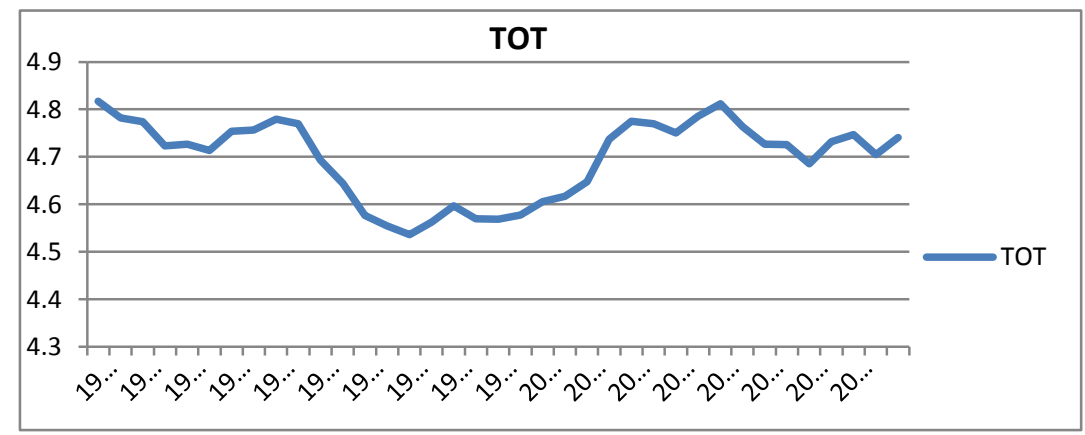

Figure A5. Evolution of TOT

Source: WB. 


\section{Appendix B. Stationary tests of the variables}

* REER

Null Hypothesis: TCRE has a unit root

Exogenous: Constant, Linear Trend

Lag Length: 0 (Automatic - based on SIC, maxlag=9)

\begin{tabular}{lccc}
\hline & & t-Statistic & Prob.* \\
\hline Augmented Dickey-Fuller test statistic & & -1.340055 & 0.8613 \\
Test critical values: & $1 \%$ level & -4.234972 & \\
& $5 \%$ level & -3.540328 & \\
& $10 \%$ level & -3.202445 & \\
\hline
\end{tabular}

*MacKinnon (1996) one-sided p-values.

Augmented Dickey-Fuller Test Equation

Dependent Variable: D(REER)

Method: Least Squares

Date: 06/20/18 Time: 10:51

Sample (adjusted): 19812016

Included observations: 36 after adjustments

\begin{tabular}{lrrrr}
\hline \multicolumn{1}{c}{ Variable } & Coefficient & Std. Error & t-Statistic & Prob. \\
\multicolumn{1}{c}{ REER (-1) } & -0.095095 & 0.070963 & -1.340055 & 0.1894 \\
\multicolumn{1}{c}{ C } & 0.457997 & 0.375519 & 1.219635 & 0.2312 \\
\multicolumn{1}{c}{ @ TREND("1980") } & -0.001008 & 0.001812 & -0.556089 & 0.5819 \\
\hline R-squared & 0.105411 & Mean dependent var & -0.023111 \\
Adjusted R-squared & 0.051194 & S.D. dependent var & 0.051612 \\
S.E. of regression & 0.050273 & Akaike info criterion & -3.063040 \\
Sum squared resid & 0.083404 & Schwarz criterion & -2.931080 \\
Log likelihood & 58.13471 & Hannan-Quinn criter. & -3.016982 \\
F-statistic & 1.944227 & Durbin-Watson stat & 0.859596 \\
Prob(F-statistic) & 0.159143 & & \\
\hline
\end{tabular}

Null Hypothesis: D(REER) has a unit root

Exogenous: Constant

Lag Length: 0 (Automatic - based on SIC, maxlag=9)

\begin{tabular}{lccc}
\hline & & t-Statistic & Prob.* \\
\hline Augmented Dickey-Fuller test statistic & & -2.966457 & 0.0481 \\
Test critical values: & $1 \%$ level & -3.632900 & \\
& $5 \%$ level & -2.948404 & \\
& $10 \%$ level & -2.612874 & \\
\hline
\end{tabular}

*MacKinnon (1996) one-sided p-values. Augmented Dickey-Fuller Test Equation Dependent Variable: D(REER,2)

Method: Least Squares

Date: 06/20/18 Time: 10:57

Sample (adjusted): 19822016

Included observations: 35 after adjustments

\begin{tabular}{lcccc}
\hline \multicolumn{1}{c}{ Variable } & Coefficient & Std. Error & t-Statistic & Prob. \\
\hline \multicolumn{1}{c}{ D(REER (-1) } & -0.420860 & 0.141873 & -2.966457 & 0.0056 \\
\hline R-squared & -0.010644 & 0.007976 & -1.334465 & 0.1912 \\
Adjusted R-squared & 0.210524 & Mean dependent var & -0.001155 \\
S.E. of regression & 0.186600 & S.D. dependent var & 0.047928 \\
Sum squared resid & 0.043225 & Akaike info criterion & -3.389331 \\
Log likelihood & 0.061658 & Schwarz criterion & -3.300454 \\
F-statistic & 61.31329 & Hannan-Quinn criter. & -3.358650 \\
Prob(F-statistic) & 8.799864 & Durbin-Watson stat & 1.555924 \\
& 0.005566 & & \\
& \multicolumn{4}{r}{}
\end{tabular}


Null Hypothesis: TOT has a unit root

Exogenous: Constant, Linear Trend

Lag Length: 1 (Automatic - based on SIC, maxlag=9)

\begin{tabular}{lccc}
\hline & & & \\
& & t-Statistic & Prob.* \\
\hline Augmented Dickey-Fuller test statistic & -1.874219 & 0.6464 \\
Test critical values: & $1 \%$ level & -4.243644 & \\
& $5 \%$ level & -3.544284 & \\
& $10 \%$ level & -3.204699 & \\
\hline
\end{tabular}

*MacKinnon (1996) one-sided p-values.

Augmented Dickey-Fuller Test Equation

Dependent Variable: D(TOT)

Method: Least Squares

Date: 06/20/18 Time: 10:58

Sample (adjusted): 19822016

Included observations: 35 after adjustments

\begin{tabular}{lrlrl}
\hline \multicolumn{1}{c}{ Variable } & Coefficient & Std. Error & t-Statistic & \multicolumn{1}{c}{ Prob. } \\
TOT(-1) & -0.134765 & 0.071904 & -1.874219 & 0.0704 \\
D(TOT(-1) & 0.310237 & 0.165959 & 1.869352 & 0.0710 \\
C & 0.621577 & 0.337137 & 1.843692 & 0.0748 \\
\multicolumn{1}{c}{ @ TREND("1980") } & 0.000560 & 0.000588 & 0.952884 & 0.3480 \\
\hline R-squared & 0.195771 & Mean dependent var & & -0.001173 \\
Adjusted R-squared & 0.117942 & S.D. dependent var & & 0.036716 \\
S.E. of regression & 0.034483 & Akaike info criterion & & -3.789474 \\
Sum squared resid & 0.036862 & Schwarz criterion & & -3.611720 \\
Log likelihood & 70.31579 & Hannan-Quinn criter. & & -3.728113 \\
F-statistic & 2.515409 & Durbin-Watson stat & & 1.981678 \\
Prob(F-statistic) & 0.076513 & & \\
\hline
\end{tabular}

Null Hypothesis: D(TOT) has a unit root

Exogenous: Constant, Linear Trend

Lag Length: 0 (Automatic - based on SIC, maxlag=9)

\begin{tabular}{lccc}
\hline & & & \\
& & t-Statistic & \multicolumn{1}{c}{ Prob.* } \\
\hline Augmented Dickey-Fuller test statistic & -4.286609 & 0.0090 \\
Test critical values: & $1 \%$ level & -4.243644 & \\
& $5 \%$ level & -3.544284 & \\
& $10 \%$ level & -3.204699 & \\
\hline
\end{tabular}

*MacKinnon (1996) one-sided p-values.

Augmented Dickey-Fuller Test Equation

Dependent Variable: D(TOT,2)

Method: Least Squares

Date: 06/20/18 Time: 10:59

Sample (adjusted): 19822016

Included observations: 35 after adjustments

\begin{tabular}{lrccr}
\hline \multicolumn{1}{c}{ Variable } & Coefficient & Std. Error & t-Statistic & Prob. \\
\hline \multicolumn{1}{c}{ D(TOT(-1)) } & -0.731972 & 0.170758 & -4.286609 & 0.0002 \\
$\quad$ C & -0.009845 & 0.013170 & -0.747476 & 0.4602 \\
\multicolumn{1}{c}{ @ TREND("1980") } & 0.000502 & 0.000610 & 0.822594 & 0.4168 \\
\hline R-squared & 0.364782 & Mean dependent var & & 0.002028 \\
Adjusted R-squared & 0.325081 & S.D. dependent var & & 0.043591 \\
S.E. of regression & 0.035812 & Akaike info criterion & & -3.739277 \\
Sum squared resid & 0.041039 & Schwarz criterion & & -3.605961 \\
Log likelihood & 68.43734 & Hannan-Quinn criter. & & -3.693256 \\
F-statistic & 9.188191 & Durbin-Watson stat & & 1.946587 \\
Prob(F-statistic) & 0.000703 & & & \\
\hline
\end{tabular}


Null Hypothesis: FDI has a unit root

Exogenous: Constant, Linear Trend

Lag Length: 0 (Automatic - based on SIC, maxlag=9)

\begin{tabular}{lccc}
\hline & & t-Statistic & \multicolumn{1}{c}{ Prob.* } \\
\hline Augmented Dickey-Fuller test statistic & -3.420046 & 0.0645 \\
Test critical values: & $1 \%$ level & -4.234972 & \\
& $5 \%$ level & -3.540328 & \\
& $10 \%$ level & -3.202445 & \\
\hline
\end{tabular}

*MacKinnon (1996) one-sided p-values.

Augmented Dickey-Fuller Test Equation

Dependent Variable: D(FDI)

Method: Least Squares

Date: 06/20/18 Time: 11:01

Sample (adjusted): 19812016

Included observations: 36 after adjustments

\begin{tabular}{lrcrr}
\hline \multicolumn{1}{c}{ Variable } & Coefficient & Std. Error & t-Statistic & \multicolumn{1}{c}{ Prob. } \\
\hline \multicolumn{1}{c}{ FDI (-1) } & -0.510349 & 0.149223 & -3.420046 & 0.0017 \\
C & 0.140475 & 0.189392 & 0.741716 & 0.4635 \\
\multicolumn{1}{c}{ @ TREND("1980") } & 0.012164 & 0.009135 & 1.331578 & 0.1921 \\
\hline R-squared & 0.262248 & Mean dependent var & & -0.005155 \\
Adjusted R-squared & 0.217536 & S.D. dependent var & & 0.605628 \\
S.E. of regression & 0.535720 & Akaike info criterion & & 1.669247 \\
Sum squared resid & 9.470880 & Schwarz criterion & & 1.801207 \\
Log likelihood & -27.04644 & Hannan-Quinn criter. & & 1.715304 \\
F-statistic & 5.865254 & Durbin-Watson stat & & 2.136555 \\
Prob(F-statistic) & 0.006615 & & \\
\hline
\end{tabular}

Null Hypothesis: OP has a unit root

Exogenous: Constant, Linear Trend

Lag Length: 0 (Automatic - based on SIC, maxlag=9)

\begin{tabular}{lccc}
\hline & & & \\
& & t-Statistic & Prob.* \\
\hline Augmented Dickey-Fuller test statistic & -2.726509 & 0.2326 \\
Test critical values: & $1 \%$ level & -4.234972 & \\
& $5 \%$ level & -3.540328 & \\
& $10 \%$ level & -3.202445 & \\
\hline
\end{tabular}

*MacKinnon (1996) one-sided p-values.

Augmented Dickey-Fuller Test Equation

Dependent Variable: D(OP)

Method: Least Squares

Date: 06/20/18 Time: 11:05

Sample (adjusted): 19812016

Included observations: 36 after adjustments

\begin{tabular}{lrcrr}
\hline \multicolumn{1}{c}{ Variable } & Coefficient & Std. Error & t-Statistic & Prob. \\
\hline \multicolumn{1}{c}{ OP(-1) } & -0.368240 & 0.135059 & -2.726509 & 0.0102 \\
C & 1.341664 & 0.492036 & 2.726757 & 0.0102 \\
\multicolumn{1}{c}{ @ TREND("1980") } & 0.002975 & 0.001581 & 1.881545 & 0.0687 \\
\hline R-squared & 0.183853 & Mean dependent var & & 0.001640 \\
Adjusted R-squared & 0.134389 & S.D. dependent var & & 0.076520 \\
S.E. of regression & 0.071193 & Akaike info criterion & & -2.367193 \\
Sum squared resid & 0.167258 & Schwarz criterion & & -2.235233 \\
Log likelihood & 45.60948 & Hannan-Quinn criter. & & -2.321136 \\
F-statistic & 3.716939 & Durbin-Watson stat & & 1.682196 \\
Prob(F-statistic) & 0.035009 & & & \\
\hline
\end{tabular}


Null Hypothesis: D(OP) has a unit root

Exogenous: Constant, Linear Trend

Lag Length: 0 (Automatic - based on SIC, maxlag=9)

\begin{tabular}{lccc}
\hline & & & \\
& & t-Statistic & Prob.* \\
\hline Augmented Dickey-Fuller test statistic & -5.588315 & 0.0003 \\
Test critical values: & $1 \%$ level & -4.243644 & \\
& $5 \%$ level & -3.544284 & \\
& $10 \%$ level & -3.204699 & \\
\hline
\end{tabular}

*MacKinnon (1996) one-sided p-values.

Augmented Dickey-Fuller Test Equation

Dependent Variable: D(OP,2)

Method: Least Squares

Date: 06/20/18 Time: 11:06

Sample (adjusted): 19822016

Included observations: 35 after adjustments

\begin{tabular}{lrccr}
\hline \multicolumn{1}{c}{ Variable } & Coefficient & Std. Error & t-Statistic & Prob. \\
\hline \multicolumn{1}{c}{ D(OP(-1)) } & -1.008862 & 0.180531 & -5.588315 & 0.0000 \\
$\quad$ C & -0.005641 & 0.028559 & -0.197540 & 0.8447 \\
\multicolumn{1}{c}{ @ TREND("1980") } & 0.000296 & 0.001330 & 0.222914 & 0.8250 \\
\hline R-squared & 0.494143 & Mean dependent var & & -0.004675 \\
Adjusted R-squared & 0.462526 & S.D. dependent var & & 0.108109 \\
S.E. of regression & 0.079258 & Akaike info criterion & & -2.150410 \\
Sum squared resid & 0.201017 & Schwarz criterion & & -2.017095 \\
Log likelihood & 40.63218 & Hannan-Quinn criter. & & -2.104390 \\
F-statistic & 15.62946 & Durbin-Watson stat & & 1.868713 \\
Prob(F-statistic) & 0.000018 & & & \\
\hline
\end{tabular}

\section{GDP}

Null Hypothesis: GDP has a unit root

Exogenous: Constant

Lag Length: 0 (Automatic - based on SIC, maxlag=9)

\begin{tabular}{lccc}
\hline & & & \\
& & t-Statistic & \multicolumn{1}{c}{ Prob.* } \\
\hline Augmented Dickey-Fuller test statistic & -0.375045 & 0.9030 \\
Test critical values: & $1 \%$ level & -3.626784 & \\
& $5 \%$ level & -2.945842 & \\
& $10 \%$ level & -2.611531 & \\
\hline
\end{tabular}

*MacKinnon (1996) one-sided p-values.

Augmented Dickey-Fuller Test Equation

Dependent Variable: D(GDP)

Method: Least Squares

Date: 06/20/18 Time: 11:08

Sample (adjusted): 19812016

Included observations: 36 after adjustments

\begin{tabular}{lrlrr}
\hline \multicolumn{1}{c}{ Variable } & Coefficient & \multicolumn{1}{c}{ Std. Error } & t-Statistic & \multicolumn{1}{c}{ Prob. } \\
\hline \multicolumn{1}{c}{ GDP $(-1)$} & -0.009589 & 0.025568 & -0.375045 & 0.7100 \\
C & 0.101215 & 0.197047 & 0.513661 & 0.6108 \\
\hline R-squared & 0.004120 & Mean dependent var & & 0.027450 \\
Adjusted R-squared & -0.025171 & S.D. dependent var & & 0.070757 \\
S.E. of regression & 0.071642 & Akaike info criterion & & -2.380332 \\
Sum squared resid & 0.174505 & Schwarz criterion & & -2.292358 \\
Log likelihood & 44.84597 & Hannan-Quinn criter. & & -2.349627 \\
F-statistic & 0.140659 & Durbin-Watson stat & & 1.536300 \\
Prob(F-statistic) & 0.709957 & & \\
\hline
\end{tabular}


Null Hypothesis: D(GDP) has a unit root

Exogenous: Constant

Lag Length: 0 (Automatic - based on SIC, maxlag=9)

\begin{tabular}{lccc}
\hline & & & \\
& & t-Statistic & \multicolumn{1}{c}{ Prob.* } \\
\hline Augmented Dickey-Fuller test statistic & -4.775619 & 0.0005 \\
Test critical values: & $1 \%$ level & -3.632900 & \\
& $5 \%$ level & -2.948404 & \\
& $10 \%$ level & -2.612874 & \\
\hline
\end{tabular}

*MacKinnon (1996) one-sided p-values.

Augmented Dickey-Fuller Test Equation

Dependent Variable: D(GDP,2)

Method: Least Squares

Date: 06/20/18 Time: 11:09

Sample (adjusted): 19822016

Included observations: 35 after adjustments

\begin{tabular}{lrcrr}
\hline \multicolumn{1}{c}{ Variable } & Coefficient & Std. Error & t-Statistic & \multicolumn{1}{c}{ Prob. } \\
\hline \multicolumn{1}{c}{ D(GDP (-1) } & -0.804431 & 0.168445 & -4.775619 & 0.0000 \\
\multicolumn{1}{c}{ C } & 0.024338 & 0.012764 & 1.906721 & 0.0653 \\
\hline R-squared & 0.408671 & Mean dependent var & & 0.000773 \\
Adjusted R-squared & 0.390752 & S.D. dependent var & & 0.089225 \\
S.E. of regression & 0.069644 & Akaike info criterion & & -2.435406 \\
Sum squared resid & 0.160058 & Schwarz criterion & & -2.346529 \\
Log likelihood & 44.61960 & Hannan-Quinn criter. & & -2.404726 \\
F-statistic & 22.80653 & Durbin-Watson stat & & 2.064819 \\
Prob(F-statistic) & 0.000036 & & \\
\hline
\end{tabular}

\section{CAB}

Null Hypothesis: $\mathrm{CAB}$ has a unit root

Exogenous: Constant, Linear Trend

Lag Length: 0 (Automatic - based on SIC, maxlag=9)

\begin{tabular}{lccc}
\hline & & & \\
& & t-Statistic & \multicolumn{1}{c}{ Prob.* } \\
\hline Augmented Dickey-Fuller test statistic & -2.111057 & 0.5225 \\
Test critical values: & $1 \%$ level & -4.234972 & \\
& $5 \%$ level & -3.540328 & \\
& $10 \%$ level & -3.202445 & \\
\hline
\end{tabular}

*MacKinnon (1996) one-sided p-values.

Augmented Dickey-Fuller Test Equation

Dependent Variable: D(CAB)

Method: Least Squares

Date: 06/20/18 Time: 11:10

Sample (adjusted): 19812016

Included observations: 36 after adjustments

\begin{tabular}{lrccr}
\hline \multicolumn{1}{c}{ Variable } & Coefficient & Std. Error & t-Statistic & \multicolumn{1}{c}{ Prob. } \\
\hline \multicolumn{1}{c}{ CAB (-1) } & -0.260559 & 0.123426 & -2.111057 & 0.0424 \\
C & -0.923600 & 0.879830 & -1.049748 & 0.3015 \\
\multicolumn{1}{c}{ @ TREND("1980") } & -0.020982 & 0.033420 & -0.627820 & 0.5344 \\
\hline R-squared & 0.124924 & Mean dependent var & & -0.131787 \\
Adjusted R-squared & 0.071889 & S.D. dependent var & & 2.158459 \\
S.E. of regression & 2.079427 & Akaike info criterion & & 4.381717 \\
Sum squared resid & 142.6925 & Schwarz criterion & & 4.513677 \\
Log likelihood & -75.87090 & Hannan-Quinn criter. & & 4.427774 \\
F-statistic & 2.355509 & Durbin-Watson stat & & 1.795047 \\
Prob(F-statistic) & 0.110600 & & & \\
\hline
\end{tabular}


Null Hypothesis: CAB has a unit root

Exogenous: Constant, Linear Trend

Lag Length: 0 (Automatic - based on SIC, maxlag=9)

\begin{tabular}{lccc}
\hline & & t-Statistic & Prob.* \\
\hline Augmented Dickey-Fuller test statistic & -2.111057 & 0.5225 \\
Test critical values: & $1 \%$ level & -4.234972 & \\
& $5 \%$ level & -3.540328 & \\
& $10 \%$ level & -3.202445 & \\
\hline
\end{tabular}

*MacKinnon (1996) one-sided p-values.

Augmented Dickey-Fuller Test Equation

Dependent Variable: D(CAB)

Method: Least Squares

Date: 06/20/18 Time: 12:58

Sample (adjusted): 19812016

Included observations: 36 after adjustments

\begin{tabular}{lrlcl}
\hline \multicolumn{1}{c}{ Variable } & Coefficient & Std. Error & t-Statistic & Prob. \\
\hline \multicolumn{1}{c}{ CAB (-1) } & -0.260559 & 0.123426 & -2.111057 & 0.0424 \\
\multicolumn{1}{c}{ @ TREND("1980") } & -0.923600 & 0.879830 & -1.049748 & 0.3015 \\
\hline R-squared & -0.020982 & 0.033420 & -0.627820 & 0.5344 \\
Adjusted R-squared & 0.124924 & Mean dependent var & & -0.131787 \\
S.E. of regression & 0.071889 & S.D. dependent var & & 2.158459 \\
Sum squared resid & 2.079427 & Akaike info criterion & & 4.381717 \\
Log likelihood & 142.6925 & Schwarz criterion & & 4.513677 \\
F-statistic & -75.87090 & Hannan-Quinn criter. & & 4.427774 \\
Prob(F-statistic) & 2.355509 & Durbin-Watson stat & & 1.795047 \\
\hline & 0.110600 & & & \\
\hline
\end{tabular}

Null Hypothesis: $\mathrm{D}(\mathrm{CAB})$ has a unit root

Exogenous: Constant, Linear Trend

Lag Length: 0 (Automatic - based on SIC, maxlag=9)

\begin{tabular}{|c|c|c|c|}
\hline \multirow{2}{*}{\multicolumn{2}{|c|}{ Augmented Dickey-Fuller test statistic }} & t-Statistic & Prob.* \\
\hline & & -5.888976 & 0.0001 \\
\hline \multirow[t]{3}{*}{ Test critical values: } & $1 \%$ level & -4.243644 & \\
\hline & $5 \%$ level & -3.544284 & \\
\hline & $10 \%$ level & -3.204699 & \\
\hline
\end{tabular}

*MacKinnon (1996) one-sided p-values.

Augmented Dickey-Fuller Test Equation

Dependent Variable: D(CAB,2)

Method: Least Squares

Date: 06/20/18 Time: 11:11

Sample (adjusted): 19822016

Included observations: 35 after adjustments

\begin{tabular}{lrlrc}
\hline \multicolumn{1}{c}{ Variable } & Coefficient & Std. Error & t-Statistic & \multicolumn{1}{c}{ Prob. } \\
\hline \multicolumn{1}{c}{ D(CAB (-1)) } & -1.033392 & 0.175479 & -5.888976 & 0.0000 \\
\multicolumn{1}{c}{ @ TREND("1980") } & 0.374702 & 0.804414 & 0.465807 & 0.6445 \\
\hline R-squared & -0.025080 & 0.037495 & -0.668902 & 0.5084 \\
Adjusted R-squared & 0.520213 & Mean dependent var & & 0.042317 \\
S.E. of regression & 0.490226 & S.D. dependent var & & 3.124398 \\
Sum squared resid & 2.230772 & Akaike info criterion & & 4.524389 \\
Log likelihood & 159.2430 & Schwarz criterion & & 4.657704 \\
F-statistic & -76.17681 & Hannan-Quinn criter. & & 4.570409 \\
Prob(F-statistic) & 17.34812 & Durbin-Watson stat & & 2.007123 \\
\hline & 0.000008 & & & \\
\hline
\end{tabular}

\section{Copyrights}

Copyright for this article is retained by the author(s), with first publication rights granted to the journal.

This is an open-access article distributed under the terms and conditions of the Creative Commons Attribution license (http://creativecommons.org/licenses/by/4.0/). 